\title{
Uten lovlig opphold = uten rettigheter? Tilværelsen til migranter uten oppholdstillatelse i lys av normativ teori om rettferdighet
}

\author{
Katrine Fangen* og Halvar Andreassen Kjærre** \\ *Institutt for sosiologi og samfunnsgeografi, Universitetet i Oslo, katrine.fangen@sosgeo.uio.no \\ ** Cocoon ressurssenter for barnevern og etnisitet, halvar@cocoon-r.no
}

Migranter som fortsetter å oppholde seg $i$ et land etter avslag på søknad om opphold, eller som unnlater å søke om oppholdstillatelse, utfordrer det juridiske rammeverket for nasjonalstater og statsborgerskap. I denne artikkelen diskuteres livssituasjonen til migranter uten lovlig opphold opp mot normativ kosmopolitisk teori om universelle rettigheter. Dette er belyst $i$ internasjonal litteratur, men $i$ mindre grad innenfor en norsk kontekst. Vi tar $i$ denne artikkelen for oss tre empiriske eksempler: tilvorelsen $i$ såkalte ventemottak, tilvorelsen utenfor ventemottakene og tilvorelsen for barn uten lovlig opphold. Gjennom eksemplene diskuterer vi rettighetsspørsmål i migrantenes liv. Vi viser hvordan menneskerettighetene ikke er tilstrekkelige for å ivareta migrantenes velvore, og hvordan rettigheter migrantene faktisk har, ikke fremstår som reelle fordi det oppleves som risikabelt å benytte seg av dem. Artikkelen setter normativ kosmopolitisk teori i perspektiv ved å diskutere den konkrete situasjonen til migrantene, og spør til slutt hva som kan vore konsekvensene av at rettigheter blir ulikt fordelt?

Nøkkelord: rettferdighet, rettigheter, migrasjon, ulovlig opphold, kosmopolitisme

\begin{abstract}
English summary: Without legal residency = no rights? A discussion of the situation of migrants who have settled without official authorisation, in light of the normative theory of justice

Migrants who continue to reside in a country after having received a negative answer to their residence application, or who stay without registering themselves in the first place, challenge the legal framework of national states and citizenship. In this article, we illustrate the situation of migrants without legal residence in light of normative cosmopolitan theory focusing on the universality of rights. We discuss three empirical contexts: life in the so-called waiting reception centers, life outside the waiting reception centers, and the situation of children without legal residence. We illustrate how human rights are not sufficient to protect migrants' well-being and how actual rights do not appear to be so because it is perceived as risky to use them. The article puts normative cosmopolitan theory in perspective by discussing the specific situation of migrants without legal residence, and it closes with the question of what happens if rights are unevenly distributed.
\end{abstract}

Keywords: justice, rights, migration, illegal residency, cosmopolitanism 


\section{Innledning}

Tanker om rettferdighet i vestlige samfunn har vært sterkt knyttet opp mot det Benedict Anderson (2006) kalte «forestilte nasjonale felleskap». Således har felles historie, kultur, identitet og opphav fungert som utgangspunkt for fordeling av rettigheter. Den økningen man ser i hele den vestlige verden av personer som oppholder seg innenfor et nasjonalt territorium uten at de har lovlig opphold, fører imidlertid til nye politiske konstellasjoner som utfordrer det juridiske rammeverket for nasjonalstater og statsborgerskap. Det er en av årsakene til at kosmopolitiske tenkere i vår tid har påpekt at man må gå på tvers av det nasjonalstatlige rammeverket når man skal vurdere hvordan rettigheter skal eller bør tildeles. Sammenkoplingen mellom statsborgerskap og rettigheter er ikke lenger en vedtatt sannhet, men et tema som er oppe til diskusjon (Fraser 2005). Det samme gjelder hva statsborgerskap innebærer, og hva man mener det bør innebære (Benhabib 2002).

Migranter uten lovlig opphold er ikke nødvendigvis fratatt alle rettigheter, men de mangler grunnleggende rettigheter som er viktig for å kunne realisere sine potensialer og fungere sosialt (Fangen \& Kjærre i trykk). Denne artikkelen analyserer migrantenes livssituasjon i lys av normativ teori. Det finnes internasjonal faglitteratur der man kopler analysen av migranter uten lovlig opphold opp mot normativ teori (f.eks. Friese 2010; Walters 2010). Men i Norge er det skrevet om denne kategorien mennesker ut fra et normativt teoretisk utgangspunkt, uten analyse av empiri (jf. Lysaker 2011). Det har imidlertid de senere årene vært foretatt relativt omfattende empirisk forskning på migranter uten lovlig opphold i Norge (Brekke \& Søholt 2005; Brunovskis \& Bjerkan 2008; Hjelde 2010; Kjærre 2010, 2011b; Valenta mfl. 2010; Valenta \& Thorshaug 2011; Valenta 2012; Øien \& Sønsterudbraaten 2011). Disse studiene supplerer våre funn, men de gjør få eksplisitte koplinger mellom det normative og det empiriske.

I denne artikkelen vil vi benytte normativ og kritisk teori som et bakteppe for diskusjonen av noen empiriske funn. Én grunn til at vi mener normativ teori er relevant som et bakteppe for forståelsen av situasjonen til migranter uten lovlig opphold, er nettopp at deres situasjon er definert ut fra mangelen på rettigheter. Et fokus på rettigheter innebærer per definisjon et normativt perspektiv. I tillegg vil vi benytte sosialkonstruktivistisk teori for å fokusere på den symbolske betydningen migrantene har i opprettholdelsen av et nasjonalt territorium.

Etter en gjennomgang av det historiske bakteppet for rettighetstankegang i en nasjonalstatlig kontekst, vil vi ta utgangspunkt i tre empiriske eksempler: tilværelsen i såkalte ventemottak, tilværelsen utenfor ventemottakene og tilværelsen for barn uten lovlig opphold. Alle eksemplene belyser rettighetsspørsmål i migrantenes liv. ${ }^{1}$ Vi viser hvordan menneskerettighetene ikke er tilstrekkelige for å ivareta migrantenes velvære, samt at de rettighetene barn har til for eksempel skolegang, ikke fremstår som reelle fordi det oppleves som risikabelt å benytte seg av dem. Teoretisk bygger artikkelen primært på Giorgio Agamben og Zygmunt Bauman som representanter for sosialkonstruktivismen, og Seyla Benhabib og Nancy Fraser som representanter for normativ teori. Disse fire teoretikerne tilhører altså to motstridende tradisjoner, men vi mener en kombinasjon av deres bidrag er fruktbart for å diskutere den humanistiske dimensjonen ved rettighetsspørsmål for migranter uten lovlig opphold. 


\section{«Uønskede andre» og sporsmålet om rettferdighet}

Fra antikkens Hellas har statsborgerskapet utviklet seg fra å være et prinsipp for lokal tilhørighet, politisk deltakelse og rettigheter i polis-staten, til et generelt prinsipp for nasjonalstatlig tilhørighet og fordeling av rettigheter og plikter (se Khosravi 2006). Etter den westfalske fredsavtalen i 1648, som innledet tenkningen om staters suverenitet, har også våre begreper om rettigheter stadig blitt utvidet til å omfatte nye grupper. Blant annet kvinner, fargede og slaver er grupper som har fått rettigheter innenfor rammen av et nasjonalstatlig felleskap, i takt med utviklingen av demokratiske prinsipper (Fraser 2005).

Fremveksten av nasjonalstater har imidlertid også foregått hånd i hånd med at visse minoriteter har falt utenfor det nasjonalstatlige rammeverket. Som Hannah Arendt (1973) understreker, ble jøder nektet statsborgerskap både av Nazi-Tyskland som de flyktet fra, og de andre landene som de flyktet til. De manglet således ikke bare rettigheter, men også «retten til å ha rettigheter» (Arendt 1973: 96). Det at ideer om individuelle rettigheter ikke kunne beskytte dem, viste i hvilken grad rettigheter kun var refleksjoner av statsmakten (Calhoun 2003).

Rettferdighet omfatter, innenfor en statssentrert orden, kun rettigheter for den nasjonale gruppen, og de fleste stater har tillatt seg å iverksette grove krenkelser overfor mennesker som ikke blir definert som fullverdige borgere (ett eksempel er tvangssterilisering av sigøynere og tatere i Norge i mellomkrigstiden og i de første tiårene etter andre verdenskrig, jf. Brochmann \& Kjelstadli 2008). I etterkant av Holocaust utviklet det seg imidlertid en bevissthet om at det var behov for å beskytte minoriteter mot krenkelser, for å unngå at noe lignende kunne skje igjen. En rekke tiltak ble iverksatt for å bedre situasjonen for statsløse personer, inkludert signering av traktater og stiftelsen av De forente nasjoners høykommissær for flyktninger (Calhoun 2003).

Felles, transnasjonale retningslinjer skulle forhindre at en stat kunne diskriminere mennesker den ikke anså som del av sin politiske enhet. Med dette utgangspunktet gikk man sammen om å utvikle menneskerettighetskatalogen som et klart signal om at man ikke ønsket den typen urett man nylig hadde vært vitne til. Meningen var at stater til en viss grad måtte forplikte seg til å stille opp for enkeltindivider. I menneskerettserklæringen av 1948 utrykkes det høye ambisjoner hva rettigheter angår:

Everyone has the right to a standard of living adequate for the health and well-being of himself and of his family, including food, clothing, housing and medical care and necessary social services, and the right to security in the event of unemployment, sickness, disability, widowhood, old age or other lack of livelihood in circumstances beyond his control. (UN 1948 Universal Human Rights Declaration, vår utheving)

Selv om ordlyden i menneskerettighetene har universelle ambisjoner, kan lovtekstene likevel forstås som den delen av internasjonal lov som regulerer individets rettigheter ovenfor en stat (se Høstmælingen 2010). En slik definisjon synliggjør en sentral kritikk, nemlig hvordan den nasjonalstatlige ordenen fortsatt er en betingelse for å få grunnleggende rettigheter oppfylt. Selv om enkelte rettigheter distribueres på bakgrunn av andre prinsipper, som oppholdstillatelse eller generell tilstedeværelse (jf. Benhabib 2004), er det i hovedsak bare dem som har statsborgerskap som får fulle borgerrettigheter. Benhabib 
påpeker at menneskerettighetene innrømmer en begrenset rett til fri bevegelse over landegrensene, det vil si retten til å emigrere, men ikke en tilsvarende rett til å immigrere, det vil si retten til å entre et annet land.

På tross av rettighetenes grenseoverskridende karakter, kan man si at de opprettholder de enkelte staters suverenitet (Benhabib 2002). Nasjonalstater bygger på et prinsipp om at det er legitimt å forsvare seg mot trusler fra utsiden, om det nå er truende krigsmakter eller forsvarsløse migranter. Benhabib (2004) hevder dette prinsippet ligner det Kant kalte «loven om gjestfrihet». Besøkende skal nyte «våre» rettigheter i den grad de ikke utgjør en trussel for «oss». Alle skal møtes med gjestfrihet så sant det ikke går ut over den som er gjestfri. I praksis ser vi da at rettferdighetstenkningen blir problematisk fordi hjelpetrengende migranter ofte defineres som en trussel. Her unnslipper ikke menneskerettighetene den nasjonalstatlige ordenenes strukturerende rammebetingelser, blant annet fordi det fortsatt er stater som signerer konvensjonene og har ansvar for implementeringen av rettighetene (Calhoun 2003), men også fordi det er lett å fraskrive seg ansvaret ved å tillegge det en annen stats ansvarsområde. Selv om det i en viss grad er overnasjonale organer som kontrollerer disse forholdene, ser vi at de som defineres som uønskede, fortsatt mangler ikke bare rettigheter, men også «retten til å ha rettigheter», slik Arendt (1973) påpeker.

Menneskerettighetene er blitt kritisert på flere områder. Om man skulle tolke tekstene ordrett, vil det være langt igjen før man vil nå frem, og man kan jo spørre seg om de høye og universelle ambisjonene som uttrykkes i teksten, kan forstås som annet enn en utopi. Hva menes for eksempel med at alle har rett til «velvære»? Noen vil mene at menneskerettighetene fungerer fordi de bygger på en universell norm der stater forplikter seg til å tilfredsstille prekære behov overfor alle mennesker, uansett tilhørighet og statsborgerskap, så lenge de befinner seg innenfor et territorium. Men i realiteten har ikke migranter uten lovlig opphold samme beskyttelse gjennom menneskerettighetene som andre migranter.

Kritiske røster har beskrevet disse migrantenes situasjon ved å trekke veksler på skikkelsen Homo Sacer, som den italienske filosofen Giorgio Agamben $(1998,2005)$ henter fra oldtidens romerlov (jf. Khosravi 2006; Kjærre 2011b). Homo Sacer er henvist til å leve i en unntakstilstand der han er fratatt alle politiske rettigheter. Ifølge Agamben (1998) er dette en nødvendig konsekvens av hvordan politisk suverene enheter er bygget opp. Homo Sacer er således den suverene statens motpol, og han er henvist til å leve et nakent liv («bare life») uten beskyttelse, selv om han likevel er inkludert gjennom at den suverene staten bestemmer at han må leve i denne tilstanden. Agamben (1989: 9) hevder at suverene stater er avhengige av denne typen subjekter, spesielt i situasjoner der de anser sine grenser for å være truet:

At once excluding bare life from, and capturing it within the political order, the state of exception actually constituted, in its very separateness, the hidden foundation on which the entire political system rested. When its borders begin to be blurred, the bare life that dwelt there frees itself in the city and becomes both the subject and the object of the conflicts of the political order, the one place for both the organization of state power and emancipation from it. 
Sosiolog Zygmunt Bauman viser til Agamben i sluttordet i Modernity and the Holocaust (1989), der han bruker Agambens beskrivelse som et eksempel på at mennesker i det moderne samfunn kan delta i ødeleggelsen av visse kategorier «andre» fordi disse andre ses som irrelevante. Bauman har også et lignende syn som Agamben på byråkratiets funksjon i den moderne staten, hvis direkte konsekvens er at mange må ta til takke med en unntakstilstand der de møtes med intoleranse og mangel på rettigheter:

The natural inclination of modern practice, construction of order, sets the limits to incorporation and admission. It calls for the denial of right, and of the grounds, of everything that cannot be assimilated - for de-legitimation of the other. As long as the urge to put paid to ambivalence guides collective and individual action, intolerance will follow - even if, ashamedly, it hides under the mask of toleration. (Which often means: you are abominable, but I, being generous, shall let you live). (Bauman 2007:8)

I hvilken grad suverene politiske enheter produserer slike rettighetsløse mennesker, er et empirisk spørsmål, men det synes å være en viss enighet om at det er dette som skjer med migranter uten lovlig opphold, spesielt når staten antas å være under press. Samtidig ser vi at nye rettighetskrav stilles med bakgrunn i menneskene som faller utenfor.

Kosmopolitiske tenkere som Fraser (2005) og Benhabib $(2002,2004)$ har i sin kritikk av det statssentrerte rammeverket argumentert for at vi trenger et nytt overnasjonalt rammeverk for å tenke om menneskerettigheter. De påpeker hvordan nasjonalstater kommer til kort når det gjelder de menneskene som oppholder seg innenfor territoriet, men som ikke gis tilgang til rettigheter fordi de ikke har lovlig opphold. I realiteten skapes det derfor A- og B-lag av mennesker, noe som heller ikke nasjonalstaten er tjent med.

Normativ politisk teori i vår tid forespeiler ofte nasjonalstatens endelikt eller bortfallet av den westfalske suverenitetsforståelsen. Men selv om de tradisjonelle oppfatningene om statssuverenitet kollapser, utøves ifølge Benhabib (2002) monopol over territorier fortsatt som en følge av innvandrings- og statsborgerskapspolitikken. Rettigheter styres langt på vei av staters suverenitet, og derfor står mange migranter uten en reell beskyttelse (jf. Benhabib 2002, 2004). I et rettighetsmessig vakuum søker migrantene andre grupper og konstellasjoner de kan realisere seg selv ut fra (Fangen \& Kjærre i trykk). Siden 1990-tallet har man sett at stadig flere grupper fremmer sine menneskerettighetskrav innenfor kollektivistiske rammer (Cowan mfl. 2001). Mennesker i vanskelige situasjoner søker sammen og finner løsninger gjennom felles identitet og ikke gjennom en individualistisk orientert, privilegert kosmopolitisk posisjon (jf. Calhoun 2003). Etniske, religiøse, eller for den saks skyld kriminelle, grupperinger blir viktige stedfortredere for migranter uten lovlig opphold i situasjoner der staten fraskriver seg ansvar for deres velvære. På denne måten bygges nye former for suverenitet med alternativ justis, og nasjonalstatens herredømme utfordres. 


\section{Rettferdighet på norsk}

Etableringen av Norge som nasjonalstat sikret rettigheter for noen, mens andre, som samer, jøder, sigøynere og tatere, ikke ble gitt de samme rettighetene (Fangen 1993; Brochmann \& Kjelstadli 2008). Rettferdighet var således tett knyttet opp mot felles kultur og historie. Over tid har Norge utviklet en mer inkluderende tankegang overfor grupper som før var definert som utenfor. Mot slutten av 1990-årene var det i økende grad migranter uten lovlig opphold som ble definert som «de uønskede andre». Ifølge data fra SSB er den norske befolkningen langt mer skeptiske overfor asylsøkere og flyktninger enn overfor arbeidsinnvandrere (Blom 2011). Det er mye som tyder på at det finnes et etnisk hierarki eller et minoritetshierarki, der migranter uten lovlig opphold er blant de mest stigmatiserte (Fangen 2008; Kjærre 2011b; Back \& Sinha 2012). Man trodde tidligere at avviste asylsøkere ikke ville bli boende i Norge (Düvell 2010) blant annet fordi det i Norge er strengere juridiske regler og mindre toleranse for irregularitet (Fangen mfl. 2010).

Den norske velferdsstaten er kjennetegnet av at det er staten som tar ansvar for individer som er avhengig av hjelp (Fangen 2008). Familie og etniske nettverk er av mindre betydning, og bistanden er svært formalisert (Hjelde \& Fangen 2006). Det gjør det vanskeligere for de migrantene som ikke har lovlig opphold, og som derfor ikke har tilgang til mange av de offentlige velferdsordningene. Årsakene til at de likevel har kommet til Norge, er blant annet å finne i utviklingen av det europeiske migrasjons- og asylsystemet (Kjærre 2011b). Migrasjonspolitikk fra Norges side er ikke kun et nasjonalt spørsmål. Gjennom tilknytning til både Schengen-avtalen og Dublin-traktaten er Norges innvandringspolitikk i høyeste grad europeisert (Brochman \& Kjelstadli 2008). Sikkerhetstiltak og migrasjonskontroll foregår således på et europeisk nivå, samtidig som de gjenspeiler Norges egenvalgte innvandrings- og utenrikspolitikk. De nasjonale forskjellene når det gjelder innvandrings- og integreringspolitikk, kommer tydelig frem når man sammenligner situasjonen for migranter uten lovlig opphold i Norge med tilsvarende i Spania, der det langt på vei er en aksept av irregularitet (Fangen mfl. 2010).

Globalisering fører til det som kan kalles en deterritorialisering av politikken (Held \& McGrew 1998: 235). Norge blander seg inn i politiske forhold langt utenfor egne grenser (både krig, migrasjon, bistand m.m.), ofte med det uttalte formål å sikre rettigheter for borgere av andre land. Det kan ses som et rettighetsprosjekt, men også som en del av et imperialistisk prosjekt. Tanken om menneskerettigheter må i begge tilfeller hevdes å stå sterkt, og som nasjonalstat kan Norge ses som et land som markedsfører seg som humanitær stormakt (Tvedt 1985: 51).

I mange tilfeller kan det være riktig å si at måten man tenker om rettferdighet i Norge, er preget av en global forståelse. I politikken som føres overfor de migrantene som ikke har lovlig opphold, kommer det likevel frem at det fortsatt er territoriell tilknytning som er avgjørende for tilgang til rettigheter. Dette går på tvers av godhetstanken til den norske merkevaren (Tvedt 1985; Hagelund 2003), som i en slik sammenheng kan fortone seg som tom retorikk tilrettelagt for å konstruere et godhetsfremmende nasjonalt «vi», slik vi skal se eksempel på i neste underdel. 


\section{Ventemottak - statens strategier ovenfor de ureturnerbare}

Etter et politisk vedtak i 2004 mistet mange avviste asylsøkere retten til å leve i ordinære asylmottak. Innskrenkningen i rettigheter skulle medføre at flere migranter reiste hjem, men dette målet ble ikke innfridd. Flere migranter fikk derimot en langt verre livssituasjon (Brekke \& Søholt 2005). Det å gjøre migrantenes liv vanskeligere, svekket i mange tilfeller deres styrke til å reise hjem (jf. Kjærre 2010). Brekke og Søholt (2005) beskriver hvordan de avviste asylsøkerne som ikke fikk hjelp av venner eller familie, hadde få andre muligheter enn å bo utendørs.

En del frivillige organisasjoner, kirken og engasjerte enkeltpersoner kritiserte vedtaket med utgangspunkt i menneskerettighetene. Slike initiativer kan ses som sivilsamfunnets forsøk på å unngå deportasjoner, samt mer overordnet å stille spørsmål ved utvisningen av noen kategorier mennesker fra medmenneskelighetens ansvarsområde (Williams 2010: 287). Det utviklet seg en situasjon der migrantene ble kasteballer mellom stat og kommune, og de ble en økonomisk belastning for kommunene. Myndighetene godtok etter hvert at migrantene skulle få et minimum av rettigheter. For å hindre at de ble boende på gata, og for at kommunene skulle slippe å ta ansvar for dem, ble det bestemt at man skulle åpne ventemottak for å gi et botilbud fra statlig hold (Valenta mfl. 2010²). Ventemottakene Lier og Fagerli ble følgelig åpnet i henholdsvis 2006 og 2007 som et forsøk på å lage en bedre løsning på situasjonen for de mange avviste asylsøkerne. Ventemottakene var delvis åpne leire for mennesker som ikke hadde fått «lovlig opphold i riket». Tilbudet skulle likevel ha en «nøktern» levestandard for at migrantene skulle motiveres til å returnere til sine hjemland. ${ }^{3}$

Ventemottakene kan sies å være eksempel på det som internasjonalt kalles «deterrence policy», eller avskrekkingspolitikk (Seeberg 2007: 43). Det å begrense migrantenes økonomiske rettigheter og tilgang til utdanning og arbeid er andre eksempler på slik avskrekking (ibid.). Med Agamben kan vi se ventemottakene som et tegn på at «a space of emergency» blir til normen, og der «exceptional forms of treatment» blir normalisert. Således er disse leirene et uttrykk for en krise i vestlig rettighetspolitikk (Agamben 1998: 175). Arendt (1973: 279) på sin side tematiserer slike leire som den rutiniserte løsningen for bosted for fordrevne personer i etterkant av andre verdenskrig. Således blir leiren til det eneste praktiske substituttet for et ikke-eksisterende hjemland, påpeker hun. Istedenfor å være et klart uttrykk for diskriminering, hevder hun at leiren må ses som en logisk konsekvens i en verden fullstendig inndelt i territorielle nasjonalstater.

Bauman (2007) beskriver hvordan mennesker som holdes utenfor den statssentrerte ordenen, konstitueres som «avskyelige» («aboninable»), samtidig som staten trenger dem, fordi den har et behov for å vise generøsitet og velvillighet. I retorikken knyttet til norsk migrasjonspolitikk ser vi nettopp en henvisning til humanisme, rettferdighet, likhet og anstendighet (Hagelund 2003: 12). I norske myndigheters presentasjon av ventemottakene gjenspeiles behovet for å fremstå som et land preget av godhet og velvilje. Daværende justisminister Knut Storberget uttalte: 
[...] ventemottakene representerer Norges gode vilje overfor dem som har fått avslag på sin asylsøknad, men som velger ikke å ta imot tilbud om hjelp til hjemreise med bistand fra Den internasjonale organisasjonen for migrasjon (IOM) og 10.000 kroner som ny startkapital. (Storberget 2010)

Selv om leirene ble sagt å være et «frivillig botilbud», så beboerne få positive ting ved stedet. I intervjuer med migrantene kom det frem at de opplevde at de hadde få muligheter til å reise hjem, på tross av tilbudene som justisministeren skisserte. Noen fikk ikke lov til å reise på grunn av mindre forseelser eller bøter de hadde pådratt seg. Andre kunne ikke reise hjem fordi landene de kom fra, ikke ville ta imot dem. Flere vurderte trusselsituasjonen i hjemlandet som svært annerledes enn norske myndigheter gjorde. Mange hadde fortsatt et håp om at de skulle få opphold, eller en oppfatning av at deres sak var behandlet feilaktig. Andre manglet gyldige dokumenter, eller de trodde det kunne hjelpe dem å holde dokumentene skjult for å hindre deportasjon eller hjemreise.

Flere mente at om de dro hjem, ville de, som Arendts (1973) jødiske flyktninger, møte en rettighetsløs tilværelse der også. Det kunne for eksempel være at de ville blitt henvist til et liv på gata fordi de ikke hadde mulighet til å tilbakebetale lånene de hadde tatt opp for å migrere. Mange prøvde derfor å unngå å bli deportert. En annen gruppe ble værende selv om de ønsket å reise hjem. De nevnte forholdene blir gjerne oppsummert gjennom å betegne migrantene som «ureturnerbare». Som «ureturnerbare» blir migrantene værende $i$ en slags unntakstilstand uten at de kan sendes ut med makt eller finner en mulighet til å forlate situasjonen selv.

Selv om ventemottakene skulle være et «midlertidig botilbud», ble flere av beboerne boende i årevis. Ansatte mente at enkelte beboere var «grodd fast på mottaket». Deres tilværelse var preget av passivitet, klientifisering og lite meningsfulle aktiviteter samt en økonomisk situasjon som begrenset sosialt liv med utenforstående til et minimum (jf. Valenta mfl. 2010). Hver leir hadde én TV, fire datamaskiner med Internett til bortimot 100 personer, ett treningsrom og noen få spill som bordtennis og biljard. De passiviserende boforholdene ble forsterket av at migrantene hele tiden måtte be om å få det de trengte, noe de fleste fant ydmykende. En av migrantene skriver:

Vi må spørre om alt vi trenger, siden vi ikke har lov til å jobbe og bare får 100 kroner per uke. Det er veldig ydmykende for en voksen person uten funksjonshemninger å måtte spørre om toalettpapir, tannkrem, såpe, klær og så videre hele tiden. (Okeny 2010)

Jengar (25) hadde bodd ved ventemottaket siden oppstarten for fire år siden, og hadde i tillegg vært asylsøker i fire år før dette (se Kjærre 2011a). Han beskrev som mange av de andre migrantene dagliglivet med vekt på den mentale belastningen det medførte:

Det er vanskelig. Hvis du bare sitter, spiser og sover så blir du mentalt utslitt. Hvis du tenker mye... aargh... Som når jeg sitter alene. Jeg tenker masse. Jeg tenker at det er åtte år av livet og jeg har ikke gjort noe. Jeg bare sitter og sover [...] Du er i en slik leir. Du må spise. Vi spiser på tre tidspunkter. [...] Vi må spise da. Om vi vil eller ikke. Hvis ikke må vi vente til neste dag. Du kan ikke ha kontroll. Det er vanskelig å gå ut. (Jengar, 25, Irak) 
Som Jengar påpekte, ønsket flere av migrantene å slippe å tenke. De beskrev tilværelsen som «mental tortur». Ettersom flere av migrantene hadde en bakgrunn preget av krig og andre vanskeligheter, er en slik logikk ikke så vanskelig å forstå. De vanskelige minnene kom tilbake gjennom mangelen på meningsfulle aktiviteter og fremtidsutsikter. Tiden på ventemottaket ble sett som både meningsløs og endeløs, slik vi også har sett blant asylsøkere generelt (jf. Brekke 2004)

Ansatte ved ventemottakene uttrykte ofte at migrantene var «kriminelle» og «farlige». Noen av migrantene er da også farlige, i og med at de er i en så psykisk ustabil tilstand. De ansatte har ikke nødvendigvis noen kompetanse til å takle slike potensielt farlige personer. Noen av de ansatte delte beboerne inn i klare kategorier av snille og slemme. Migrantene oppfattet enkelte som jobbet der som aggressive og uvennlige, men følte også at noen var empatiske og snille. Mange ansatte hadde også en nyansert oppfatning av beboersammensetningen og påpekte at det var et problem at frustrerte mennesker med så mange forskjellige bakgrunner ble plassert på samme sted. Den vanskelige situasjonen til beboerne, forsterket av de dårlige boforholdene, hadde flere ganger ført med seg slåsskamper, opprør, sultestreiker, selvmordsforsøk og selvskading. Det gikk til tider hardt ut over inventaret. Begge leirene var preget av konfliktsoner, spesielt i områdene der de ansatte møtte personalet, eller i fellesrommene der migrantene møttes. Noen eksempler var resepsjonen, kantinen, TV-rommet og datarommet.

Høye gjerder, elektroniske porter og overvåkningskameraer med mer materialiserte den kriminaliserende oppfatningen av disse migrantene. Inngjerdingen ble brukt for å kontrollere migrantene og holde uvedkommende utenfor, men også av sikkerhetsmessige årsaker. Hele mottaket fikk således preg av å være en total institusjon i Goffmans (1967) terminologi. Ved at de på denne måten ble innesperret, følte migrantene seg kriminalisert, men de opplevde også at de til en viss grad ble beskyttet fra andre beboere som hadde bevæpnet seg, for eksempel med kniv (jf. Valenta mfl. 2010).

Mohammed (32) spurte: «[D]e sier at porten er til for å beskytte oss. Hva mener de med det? Problemet er allerede på innsiden av denne leiren, det er her problemene er.» Den delvis lukkede arkitekturen til leirene og retorikken rundt migrantene som kriminelle skapte et miljø der migrantene også begynte å se seg selv som et problem. Selvkritikk og skam var resultatet av det som kan beskrives som dehumaniserende forhold.

Det gjør vondt å sitte her med en følelse av å være en misbruker av asylsystemet. De av oss som bor på Fagerli er ikke regulære asylsøkere. Vi blir sett på som mennesker som prøver å utnytte systemet, og vi blir satt her på Fagerli. For oss er Fagerli endestasjonen. Vi er ikke asylmisbrukere, men vi starter å tenke på oss selv som asylmisbrukere. Dette terroriserer hodet vårt hver eneste dag. (Behrouz, 31, Iran)

Det å motivere til retur ble under slike forhold sett som vanskelig både av de ansatte og av andre involverte. Som institusjon i «velferdsstatens grenseland» var det en annen funksjon som ble ventemottakenes viktigste, nemlig «signaleffekten». Leirene skulle gjøre det lite fristende for andre å prøve å få opphold i Norge. De fungerte som symbolske markører som markerte nasjonalstatens grenser i en tid der disse var under press (jf. Agamben 1998). Migrantenes lidelser, og kringkastingen av dem, er derfor også symboler i kampen 
om å markere grensen. Menneskers liv og kropper blir redusert til brikker i opprettholdelsen av den nasjonalstatlige orden. For Agamben (2005) er leiren det paradigmatiske symbol på statlig suverenitet, som materialiseres i forskjellige former: Guantanamo, nazistenes dødsleire eller asylmottak. Disse er rom som ut ifra et statssentrert verdenssyn normativt ikke skal eksistere, men som oppstår som et resultat av det samme verdenssynet. Disse rommene viser hvordan menneskers rettigheter innskrenkes for at orden skal opprettholdes. Migrantene blir således fratatt sitt potensial. Likefullt må de sikres et minimum av sikkerhet og velvære, noe som illustreres ved at sentrene også har egne helsetilbud.

Migrantene gjorde opprør mot de dårlige boforholdene på ventemottakene gjennom individualisert dagligdags motstand, sultestreiker og selvskading. Sommeren 2010 skjedde det et kollektivt opprør på begge ventemottakene samtidig da migrantene brant begge leirene ned til grunnen.

\section{Å leve utenfor - rettferdighet i frihetens fangenskap}

Ikke alle migranter uten lovlig opphold så det som mulig å bo i mottakssystemet. De som ikke er ureturnerbare, men står i fare for å bli deportert, vil ofte holde seg utenfor mottakssystemet og er i stor grad avhengig av hjelp fra andre for å overleve (jf. Brunovskis \& Bjerkan 2008). De som hjelper migrantene, begår samtidig en lovovertredelse (Øien \& Sønsterundbraaten 2011). Når det blir mer eller mindre vanntette skott mellom nasjonalstatene, og migrantenes overlevelsesmuligheter blir få, ser ikke myndighetene noen andre muligheter å forholde seg til migrantene på enn ved å internere dem. Migrantenes eneste utvei hvis de ikke godtar dette, er enten å være prisgitt andres velvilje eller i verste fall å livnære seg gjennom kriminalitet.

Fra norske myndigheters side er internering lite brukt. Samtidig ser vi en utvikling der holdningen ovenfor migrantene blir mer rigid. Nestekjærlighet og medmenneskelighet får mindre plass i dette bildet. Det kan således oppstå et motsetningsforhold mellom stat og deler av sivilsamfunnet, fordi ideer om rettferdighet går på tvers av det staten foretar seg. I Norge, som i de andre skandinaviske landene, står ideer om likhet sterkt. På den ene siden kan det hevdes at dette kommer migrantene til gode. På den andre siden kan man også tenke seg at likhetstankegangen fører til mer eksklusjon (jf. Gullestad 2006). Det skjer blant annet når nasjonalstatens monolittiske blikk fornekter annerledeshet gjennom en offentlig fremstilling av kulturen som enhetlig (Bauman 2007).

I enkelte land, som i Spania, føres en politikk der en stor grad av irregularitet er akseptert (Fangen mfl. 2010). I Norge, derimot, er man opptatt av å sende et klart signal til senderlandene om at livet som migrant uten lovlig opphold er ulevelig. Konsekvensen av norsk asylpolitikk er at de som har fått avslag på sine søknader, men ikke reiser frivillig tilbake til hjemlandet, står utenfor de beskyttende institusjonene i samfunnet (Brekke \& Søholt 2005). Slik Bauman (2007) påpeker, kan dette ses som et resultat av en høyt utviklet byråkratisk orden. Et eksempel er retten til å ta opp lønnsarbeid. Siden migrantene ikke har rettigheter i arbeidslivet, blir de sårbare på flere plan. Det blir for eksempel vanskelig 
å planlegge, bosituasjonen blir usikker, mangel på penger gjør det vanskelig å delta i sosialt liv, og relasjonen til hjemlandet brytes, noe som gjør det enda vanskeligere å reise hjem.

Migrantene kan motta hjelp av frivillige, men står da i fare for utbytting, eller de mister verdigheten gjennom å bli det Fraser (2005:77) kaller «objects of charity». De kan jobbe svart i butikker, restauranter eller andre steder, men mange må fornekte sitt menneskelige potensial ved å motta uakseptabelt lave lønninger og gjøre arbeid ingen andre vil utføre. Likevel opplever mange av migrantene det som bedre å ha noe å gjøre enn å være stillesittende. Det handler om å ha noe å bedrive tiden med, slik at de slipper å tenke for mye på det som er vanskelig. Arbeidsgiverne er på den ene siden hjelpsomme ved å tilby arbeid, men på den annen side bryter de loven ved å gi jobb til mennesker uten lovlig opphold, og mange utnytter også migrantenes sårbare situasjon. Og selv om noen migranter får jobb, er jobbene usikre, kortvarige og lavt lønnet, og arbeidsforholdene er som regel dårlige.

Migrantene er likevel ikke fullstendig ekskludert fra samfunnet for øvrig (jf. Øien \& Sønsterudbraaten 2011). Selv om de ekskluderes gjennom lover og byråkratiske prosesser, inkluderes de også, for eksempel av frivillige organisasjoner eller sivilsamfunnet lokalt, $\mathrm{i}$ etniske grupperinger eller kriminelle institusjoner. Spørsmålet handler om hvilke måter de inkluderes på, og på hvilke arenaer dette skjer (jf. Fangen \& Kjærre i trykk). Kristne og muslimske menigheter, etniske nettverk eller veldedige organisasjoner er steder der de kan delta og spørre om hjelp. Noen av disse enhetene er innrettet spesielt for å håndtere utfordringene migrantene står overfor. Likefullt finner mange at det å få hjelp går på bekostning av verdigheten:

Når du skal spørre om hjelp, det er skamfullt, og du blir nervøs, for du vet aldri hvordan denne personen vil svare deg. For eksempel nå jeg hører fra en venn at noen kan hjelpe. Jeg ringer dem, men jeg vet aldri hvordan de vil svare. (David, 25, Iran)

Å få hjelp innebærer en ambivalens. For å få hjelpen må migrantene gå på akkord med seg selv for å tilfredsstille viktige behov. De gjør seg avhengig av mennesker de ikke nødvendigvis ville valgt å tilbringe tid med under normale omstendigheter, og de blir nødt til å gjøre arbeid de kanskje finner nedverdigende. De «ureturnerbare» kan alltids trekke seg tilbake til et mottak om forholdene blir for ille. Men for de som står i fare for å bli deportert, er ikke dette en mulighet, og de må ta de mulighetene de får. Overgangen mellom hjelp og utbytting er her glidende. Nye former for utbytting oppstår fordi migrantene ikke har lovlig opphold, samtidig som de kanskje har forpliktelser om tilbakebetaling av gjeld eller ansvar for å sende penger til familie i hjemlandet.

\section{Barnas plass i den statssentrerte orden}

Barn av avviste asylsøkere er ikke nødvendigvis «frivillig» i det landet de har flyttet til, samtidig opplever de ikke alltid tilhørighet andre steder, heller. Enkelte barn kan ha oppholdt seg i Norge i årevis og føler at det er her de hører hjemme. Noen av dem husker 
knapt sitt opprinnelsesland eller har aldri vært der. Ideen som ligger til grunn for den nasjonalstatlige ordenen, nemlig at alle har et opprinnelsesland, gjelder ikke for disse barna. Likevel følger myndighetene et prinsipp om at menneskers tilhørighet defineres ut fra foreldrenes bakgrunn. Barna gjøres slik til objekter som kan flyttes ut fra andres forgodtbefinnende, og de tillegges ikke egne rettigheter. Myndighetenes retorikk om retur blir problematisk når det gjelder denne gruppen, for hvordan kan noen returneres til et land der de ikke har vært? Som Jan Erik Vold (2012) påpeker i sitt dikt «Enkel språklære», er det i slike situasjoner ikke retur dette handler om, men deportasjon. Tilsvarende tolker Agamben (1998) slike utvisninger som deportasjoner og som uttrykk for maktutøvelse.

Agambens perspektiv kan ses som ganske pessimistisk. I så henseende er det derfor viktig å se alle de forsøkene på folkelig motstand som både leirene og utvisningene er blitt møtt med (Williams 2010: 287). Utvisning av barn er eksempel på myndighetshandlinger som til dels går på tvers av norske borgeres rettferdighetssans. Kulturelt står barnas posisjon sterkt i Norge. I en høringsuttalelse til barnekonvensjonen omtaler for eksempel Barneombudet Norge som et foregangsland når det gjelder barndoms- og likestillingspolitikk (jf. Seeberg 2007: 38). Barna er også viktige for følelsen av nasjonal tilhørighet (Gullestad 2006; Seeberg 2007). For eksempel har de en helt sentral rolle på 17. mai, som er det viktigste ritualet for å konsolidere nasjonal tilhørighet (Gullestad 2006). Samtidig har barn uten lovlig opphold blitt symboler på mennesker som er frarøvet sine rettigheter. Det er mange som reagerer med harme overfor myndighetenes behandling av disse barna.

Ideer om rettferdighet utfordres i slike sammenhenger fordi det oppleves som at man går på tvers av nasjonalfølelsen. Det er ikke uvanlig å høre at folk «skammer seg over å være norsk» når det er snakk om disse barna. Sivilsamfunnet har mobilisert mye støtte overfor barna og deres familier. Kanskje er dette også utgangspunktet for at myndighetene gir barna tilgang til enkelte rettigheter, selv om de ikke gir dem lovlig opphold. For eksempel har alle barn i Norge, uansett oppholdsstatus, rett til skolegang og helsetjenester. For de barna som ikke har lovlig opphold, er likevel problemet at dette ikke nødvendigvis er reelle rettigheter. Når de ikke har den mest grunnleggende rettigheten, nemlig retten til å oppholde seg i riket, kan det bli vanskelig å få tilgang til godene. Eksemplet belyser hvordan barna har rettigheter, men mangler «retten til rettigheter» (Arendt 1973), det vil si muligheten til å bruke dem.

Siden foreldrene er fratatt sine rettigheter, går dette hardt utover barna. Forholdet mellom barn og foreldre kan endres drastisk på grunn av den manglende legaliseringen. Chicha (34) bodde på et norsk asylmottak da han møtte Nora, og sammen fikk de datteren Joy. Etter dette fikk Chicha avslag på asylsøknaden. Han fortalte hvordan det påvirket relasjonene til datteren:

Om politiet kommer og ser etter meg... vet de at Joy og Nora er der. Derfor kan jeg ikke bo med dem, fordi de kommer til å se etter meg hos dem først. Hvis jeg vil se dem må vi gå et annet sted... ut, på et annet sted. De sier at hvis jeg vil se barnet mitt må jeg dra hjem [til Afrika] først og så komme tilbake, jeg tenker... men det er ikke lett - de må endre seg, dette er ikke normalt... Jeg bare gråter. Voksen mann som gråter... (Chicha, 34, Ghana) 
Om Chicha dro hjem, så han få muligheter til å treffe sin datter igjen. Han fikk ikke opphold i Norge, og Nora ville slite med å få ham hit fordi hun ikke tjente nok penger til å imøtekomme myndighetenes krav om økonomisk forsørgelse til å få innvilget familiegjenforening.

Barna lider under foreldrenes psykiske problemer, traumer og manglende muligheter til å ta seg av dem (Øien \& Sønsterudbraaten 2011). Enkelte barn trekker seg tilbake fra sosialt liv fordi de ikke føler de er verdsatt eller kan delta på lik linje med andre. Samtidig er de fleste barn i en slik situasjon også redde for deportasjon eller bekymret over egne og foreldrenes fremtidsutsikter. De vet de kanskje vil bli sendt et annet sted, men vet ikke helt til hva. Mediedekningen med bilder fra krig, fattigdom og sult bidrar til å forme tankene om hva som venter dem. Slike situasjoner påvirker også utbyttet barna har av skolegang. Det blir vanskelig å konsentrere seg om å lære.

Yngre barn kan tenke at det er foreldrenes feil at det er blitt slik. De eldre forstår mer og får ofte en omsorgsrolle overfor foreldrene, blant annet som deres tolk og bindeledd til resten av samfunnet (Kjærre 2011). Rashid var en av dem som fikk en slik rolle. Han fortalte om sin yngre bror:

Nå som han er elleve, begynner han å forstå hva som skjer rundt ham. Han lurer på hvorfor dette skjer. Hvorfor vi ikke kan leve som andre mennesker. [...] Det virker som det har en slags psykologisk effekt på ham. Fordi han ikke kan håndtere alt som voksne håndterer. Han begynner på en måte å bli... trist. Han isolerer seg fra de andre i familien, begynner å tenke at det er vår feil. Han sier det er de voksne sin feil at vi er i denne situasjonen. Fordi foreldrene ikke snakker norsk begynner de andre barna på skolen å erte ham. (Rashid, 24, Iran)

Både foreldre og barn er fratatt muligheten til å kontrollere egen hverdag og egne fremtidsutsikter. Siden både fremtid og dagligliv er preget av usikkerhet knyttet til sosiale forhold, økonomi, redsel for deportasjon eller psykiske utfordringer som skyldes den manglende legaliseringen, får ikke alltid barna utbytte av rettighetene sine. Foreldrene skylder ofte på myndighetene og påpeker at de ikke har noe valg. Myndighetene skylder på foreldrene, noe som i enkelte tilfeller fører til tvungen omsorgsovertakelse. På grunn av slike forhold, eller redselen for deportasjon, kan foreldre være redde for å ta med barna til skole eller lege (jf. Hjelde 2009). De kan nekte å la dem gå på skolen, eller si at de ikke får lov til å gå ut for å leke med andre barn, for de er redde politiet skal ta fra dem barna eller bruke barna for å fremtvinge deportasjon.

En egen kategori i denne sammenhengen er enslige mindreårige som har fått avslag på asylsøknaden. Noen av dem lever synlig for norske myndigheter og får omsorg i bofelleskap. Ifølge loven kan ikke norske myndigheter returnere dem før de blir 18. Der det å bli 18 år for norske ungdommer betyr mer frihet og flere rettigheter, som rett til å ta førerkort, stemmerett og rett til å komme inn på utesteder og få kjøpe alkohol, betyr 18-årsdagen for mange av disse ungdommene at de må begynne å skjule seg fra myndighetene, avslutte skolegangen osv.

Barns uskyld forsvinner med årene. Uten lovlig opphold vil mange falle utenfor med én gang de ikke lenger har tilgang til ordinær skolegang. Utekontakten i Oslo kalkulerer med at det er ca. 90-200 barn som til enhver tid lever alene på gata i hovedstaden, og de 
livnærer seg ofte gjennom kriminalitet. Deportasjoner kan føre til etablering av kriminelle nettverk (Fangen \& Kjærre i trykk). Hvordan de barna som har vokst opp i Norge, men uten lovlig opphold, vil reagere i tiden som kommer, er uvisst. Noen vil gjøre opprør mot en situasjon som fremstår som urettferdig. Blom-Hansen og Stepputat (2005) påpeker suverenitetens motpol, som består i at migrantene oppretter nye suvereniteter i det illegaliserte rommet. Eksemplet deres er det voldelige dramaet som utspiller seg på grensen mellom USA og Mexico. Vi har ikke sett denne typen konsekvenser i Norge ennå, men barna som har levd i Europa i årevis, og som nå livnærer seg gjennom småkriminalitet, kan kanskje ses som en begynnelse på noe mer organisert. Hvordan disse barna vil te seg når de vokser opp, er uklart, og en avgjørende faktor vil være hvilke rettigheter som blir gitt dem.

\section{Konklusjon}

I denne artikkelen har vi pekt på at legalt opphold er en betingelse for å få rettigheter oppfylt i Norge, selv om landet offisielt har en mer global og human rettighetstankegang (Tvedt 1985; Hagelund 2003). Migranter uten lovlig opphold utfordrer en konservativ territoriell forståelse av rettigheter. Eksemplene i vår artikkel viser hvordan de universelle rettighetene ikke alltid er reelle fordi det oppleves som for risikabelt å benytte seg av dem. Med sosialkonstruktivistiske teoretikere som Bauman og Agamben blir det mulig å analysere hvordan migranter uten lovlig opphold fremstår som symbolske brikker i opprettholdelsen av en nasjonalstatlig orden. Agamben (1998) hevder at vår tids flyktningkrise og det økende antall migranter som er involvert i svart arbeid og som står uten lovlig opphold, illustrerer et voksende sprik mellom en politikk basert på nasjonalstatens rammer og det nakne liv.

Likevel gir menneskerettighetene en legitimitet til disse migrantenes ulike forsøk på motstand. Felles for kosmopolitiske, kritiske samfunnsvitere som Benhabib og Fraser er at, selv om de påpeker den fortsatte nasjonalstatlige dominansen i sine publikasjoner om rettigheter, ser de et frigjørende potensial i menneskerettighetene og andre universelle rettigheter. Som Benhabib (2009: 694) sier:

Human rights norms, such as freedom of speech, association, and assembly, are also citizens' rights, subtending and enabling collective action and resistance to the very processes of rapacious capitalist development that postcolonial Marxist critics of 'humanitarian intervention' also decry.

Menneskerettighetene kan imidlertid forstås som en paradoksal ordning: Det å sikre migranter uten lovlig opphold grunnleggende trygghet og velvære står i motsetning til myndighetenes ønske om å vise at det ikke er attraktivt å søke seg til landet dersom man ikke er kvalifisert til det ut fra de rammene som migrasjonspolitikken har satt. Således kan de tankene om universelt statsborgerskap som fremmes av kosmopolitiske tenkere, ses som en utopi. Benhabib (2002: 465) påpeker at så lenge migranter uten lovlig opphold «are treated as if they were criminals by existing policies, cosmopolitanism in the international area has not been attained». Likevel er en tankegang inspirert av kritisk teori 
viktig idet den fremmer et mulig frigjørende potensial ved å stille spørsmålet: Hva skal til for å endre situasjonen? Som en motvekt til fokus på endringspotensialet kan særlig Agamben fremstå som mer pessimistisk i sin påpekning av utvisningsleire og deportasjon som uttrykk for maktutøvelse. Med Fraser og Benhabib vil vekten kunne forskyves til et fokus på migrantenes motstand og støtteaksjoner blant frivillige, som viser potensial for endring, og som utfordrer den rådende territorielle diskursen.

\section{Noter}

1 Eksemplene er hentet fra den ene artikkelforfatterens datamateriale, som omfatter 56 intervjuer med migranter uten lovlig opphold i Norge og ett års feltarbeid blant samme kategori mennesker. Andre som har jobbet med denne kategorien på forskjellige måter, har også vært intervjuet (se mer om det metodiske grunnlaget i Kjærre 2011b).

2 En del av datamaterialet som er samlet inn av den ene artikkelforfatteren og brukt i denne artikkelen, er også datamateriale som er brukt i evalueringen av ventemottakene (Valenta mfl. 2010).

3 Selv asylmottakene var bevisst nøkterne fra myndighetenes side fordi «[1]ivet og tilbudet i mottak skal ikke være så attraktivt at det kan friste til å søke om asyl av den grunn alene» (UDI 2006, referert i Seeberg 2007).

\section{Litteratur}

Agamben, G. (1998) Homo Sacer: Sovereign power and bare life. Stanford, CA: Stanford University Press.

Agamben, G. (2005) State of Exception. Chicago, IL: University of Chicago Press.

Anderson, B. (2006) Imagined communities: Reflections on the origin and spread of nationalism. London: Verso.

Arendt, H. (1973 [1964]) The origins of Totalitarianism. New York: Harcourt Brace Jovanovich.

Back, L. \& Shamser, S. (2012) New hierarchies of belonging, European Journal of Cultural Studies, 15 (2), s. 139-154.

Bauman, Z. (1989) Modernity and the Holocaust. London: Polity Press.

Bauman, Z. (2007 [1991]) Modernity and ambivalence. Cambridge: Polity Press.

Benhabib, S. (2002) Transformations of citizenship: The case of contemporary Europe, Government and Opposition, 37 (4), s. 439-465.

Benhabib, S. (2004) The rights of Others: Aliens, residens and citizens. Cambridge: Cambridge University Press.

Benhabib, S. (2009) Claiming rights across borders: International human rights and democratic sovereignty. American Political Science Review, 103 (4), s. 691-704.

Blom, S. (2011) Holdning til innvandrere og innvandring. SSB-rapport nr. 41. Oslo: Statistisk sentralbyrå.

Blom-Hansen, T. \& Stepputat, F. (2005) Sovereign bodies: Citizens, migrants, and states in the postcolonial world. New Jersey: Princeton University Press.

Brekke, J.P. (2004) While we are waiting: Uncertainty and empowerment among asylum-seekers in Sweden. Oslo: Institutt for samfunnsforskning. 
Brekke, J.P. \& Søholt, S. (2005) I velferdsstatens grenseland: En evaluering av ordningen med bortfall av botilbud $i$ mottak for personer med endelig avslag på asylsøknaden. Oslo: Institutt for samfunnsforskning.

Brochmann, G. \& Kjelstadli, K. (2008) A history of immigration: The case of Norway 900-2000, Oslo: Universitetsforlaget.

Brunovskis, A. \& Bjerkan, L. (2008) Learning about illegals: Issues and methods. Research with irregular migrants in Norway: Methodological and ethical challenges and emerging research agendas, s. 18-58. Oslo: Fafo.

Calhoun, C. (2003) 'Belonging' in the cosmopolitan imaginary. Ethnicities, 3 (4), s. 531-568.

Cowan, J.K., Dembour, M-B. \& Wilson, R.A. (red.) (2001) Culture and Rights: Anthropological Perspectives. Cambridge: Cambridge University Press.

Fangen, K. (1993) Rasismens historie og forhistorie. Forskningsrapport nr. 3. Sogndal: Høgskulen i Sogn og Fjordane.

Fangen, K. (2008) Identitet og praksis: Etnisitet, klasse og kjønn blant somaliere i Norge. Oslo: Gyldendal Akademisk.

Fangen, K., Mohn, F.A. \& Fossan, K. (red.) (2010) Inclusion and Exclusion of Young Adult Immigrants: Barriers and Bridges. Surrey: Ashgate.

Fangen, K. \& Kjærre, H.A. (i trykk) Ekskludert av staten, inkludert i hva? I Den nye kontrollen av de fremmede: straff, statsborgerskap og migrasjon, red. K. Franko Aas, N. Johannessen \& T. Ugelvik. Oslo: Universitetsforlaget.

Fraser, N. (2005) Reframing justice in a globalizing world. New Left Review, 36, s. 69-88.

Goffman, Erving (1967) Anstalt og menneske: Den totale institution social set. København: Paludan.

Gullestad, M. (2006) Plausible prejudice: Everyday experiences and social images of nation, culture and race. Oslo: Universitetsforlaget.

Hagelund, A. (2003) The importance of being decent: Political discourse on immigration in Norway 1970-2002. Oslo: Unipax.

Held, D. \& McGrew, A. (1998) The end of the old order? Globalization and the prospects for world order. Review of International Studies, 24 (5), s. 219-243.

Hjelde, K.H. \& Fangen, K. (2006) Oppfølging, respekt og empowerment: Somalieres forståelse og hjelpepraksis ved psykososiale vanskeligheter. Norsk tidsskrift for migrasjonsforskning, 7 (2), s. 79-99.

Hjelde, K.H. (2009) «Jeg er alltid bekymret»: Udokumenterte migranter og deres forhold til helsetjenestene i Oslo. Oslo: Nasjonal kompetanseenhet for minoritetshelse.

Hjelde, K.H. (2010) Irregular migration, health, and access to health services in Oslo. In Irregular migration in a Scandinavian perspective, red. T.L. Thomsen, M.B. Jørgensen, S. Meret, K. Hviid \& H. Stenum, s. 319-341. Maastricht: Shaker Publishing

Høstmælingen, N. (2010 [2005]) Hva er menneskerettigheter? Oslo: Universitetsforlaget.

Khosravi, S. (2006) Territorialiserad mänsklighet: Irreguljära immigranter och det nakna livet. I Om välferdens gränsar och det villkorade medborgarskapet, SOU, s. 283-310. Stockholm: Svenska Offentliga Utredningar.

Kjærre, H.A. (2010) No direction home - the margins of a welfare state and the illegalized body. I Irregular migration in a Scandinavian perspective, red. T.L. Thomsen, M.B. Jørgensen, S. Meret, K. Hviid \& H. Stenum, s. 231-259. Maastricht: Shaker Publishing.

Kjærre, H.A. (2011a) Coping with illegalization in Norway. EUMARGINS Illustrative Case. Lastet ned 26. august 2011 fra: http://www.sv.uio.no/iss/english/research/projects/eumargins/illustrative-cases/documents/jengar-illustrative-case-final.pdf

Kjærre, H.A. (2011b) In a space of everyday exception - day-to-day life and illegality among rejected asylum-seekers in Norway. Upublisert masteroppgave, Universitetet i Oslo. Lastet ned 14. juni 2012 fra: http://www.duo.uio.no/sok/search.html?q=halvar 
Lysaker, O. (2011) Anerkjennelse og menneskeverdets forankring - henimot en transnasjonal anerkjennelsespolitikk. Etikk i praksis - Nordic Journal of Applied Ethics, 5 (2), s. 101-122.

Okeny, F. (2010) Our pain and humiliation in Norway: Life in ventemottak. Tale fra beboer ved Lier ventemottak på seminaret «Ydmykelse som våpen og konfliktskaper», arrangert av Oslo kommune, Bydel Grünerløkka, 2. juni 2010. Lastet ned 5. oktober 2012 fra: http://www.facebook.com/notes/beboere-ventemottak/our-pain-and-101humiliation-in-norway-life-inventemottak/395700569404? ref $=\mathrm{mf}$

Seeberg, M.L. (2007) Utenfor den nasjonale kroppen: barn/asylsøker. Tidsskrift for norsk migrasjonsforskning, 8 (2), s. 35-48.

Storberget, K. (2010) Frivillig å veere i ventemottak. Tale 13. april 2010. Lastet ned 29. juni 2012 fra: http://www.regjeringen.no/nb/dep/jd/aktuelt/taler_og_artikler/ministeren/ justisminister_knut_storberget/2010/Frivillig-a-vare-i-ventemottak.html?id=600324

Tvedt, T. (1985) Etikk og forskning i utviklingsland. Oslo: Norges forskningsråd.

Valenta, M., Thorshaug, K., Molden, T.H. \& Berg, B. (2010) Avviste asylsøkere og ventemottaksordningen: mellom passiv tvang og aktiv returassistanse. Trondheim: NTNU Samfunnsforskning, Lastet ned 14. juni 2012 fra: http://samforsk.no/Sider/Publikasjoner/Avvisteasyls\%C3\%B8kere-og-ventemottaksordningen.aspx

Valenta, M. \& Thorshaug, K. (2011) Failed asylum seekers' responses to arrangements promoting return: Experiences from Norway. Refugee Survey Quarterly, 30 (2), s. 1-23.

Valenta, M. (2012) Avviste asylsøkere, kamp mot uttransportering og livet utenfor mottakssystemet. I Asylsøker: I velferdsstatens venterom, red. M. Valenta \& B. Berg, s. 225-247. Oslo. Universitetsforlaget.

Vold, J.E. (2012) Enkel språklære. Dagsavisen, 7. mai 2012. Lastet ned 29. juni 2012: http:// www.dagsavisen.no/kultur/jan-erik-vold-dikter-for-nathan-7-/

Walters, W. (2010) Deportation, expulsion, and the international police of aliens. Citizenship Studies, 6 (3), s. 265-292.

Øien, C. \& Sønsterudbråten, S. (2011) No way in, no way out? A study of living conditions of irregular migrants in Norway. Oslo: Fafo. 